\title{
71. EARLY PRODUCTS OF CHLOROPHYLL DIAGENESIS IN JAPAN TRENCH SEDIMENTS OF DEEP SEA DRILLING PROJECT SITES 434, 435, AND 436
}

\author{
J. William Louda, Susan E. Palmer, ${ }^{1}$ and Earl W. Baker, \\ College of Science, Florida Atlantic University, Boca Raton, Florida
}

\section{INTRODUCTION}

A relatively well documented record of intermediate and late chlorophyll diagenesis in marine sediments now exists. Intermediate diagenetic stages include conversion of chlorins to DPEP-series porphyrins and subsequent chelation with nickel, vanadyl, and, in special cases, copper. Increasing thermal stress leads to etio-series generation and transalkylation (Baker, 1969; Baker and Smith, 1975; Baker et al., 1977; Palmer and Baker, in press). In contrast, the early transformations of clorophyll are still largely unknown. Very early diagenetic reactions must certainly include loss of magnesium, deesterification, decarboxylation, reduction of ring-conjugating groups, and finally, oxidative-aromatization of carbons 7 and 8 in ring IV to yield free-base porphyrins (Baker and Smith, 1973; Smith and Baker, 1974).

Chlorins (7,8-dihydroporphyrins) are very difficult to isolate and identify, because of hydrocarbon impurities which absorb in the blue to violet region of the electromagnetic spectrum and which co-chromatograph with the pigments. Further complications possibly can arise from artifact formation during isolation.

In the present study, twelve DSDP Leg 56 core samples, ranging in sub-bottom depth from 4 to 420 meters and in age from Pleistocene to middle Miocene, were analyzed for tetrapyrrole pigments. Chlorins, in concentrations ranging from about 4 to less than 0.002 $\mu \mathrm{g} / \mathrm{g}$ sediment, wet weight, were the only tetrapyrroles found. A carotenoid (tetraterpene) was isolated from Section 434-1-3.

\section{SAMPLES AND PROCEDURES}

The samples chosen for study are from three sites in the Japan Trench: Site 434, in the accretionary wedge on the landward (west) wall; Site 435, in undisturbed sediments on the upper slope of the landward wall; and Site 436, on the seaward trench slope, representing an undisturbed sedimentological record for the Pacific Plate near the Japan Trench. Sediments of Sites 434 and 435 are generally anaerobic and rich in $\mathrm{H}_{2} \mathrm{~S}$ and biogenic $\mathrm{CH}_{4}$, whereas those of Site 436 lack $\mathrm{CH}_{4}$ and are

\footnotetext{
${ }^{1}$ Present address: Cities Service Company, Exploration and Production Research, Box 50408, Tulsa, Oklahoma 74150.
}

highly alkaline down to about 80 meters (site reports, this volume).

Samples were received and stored frozen until extraction. However, during transit from the Glomar Challenger to Scripps Institution of Oceanography, DSDP, the samples were thawed for an undetermined period of time (K. A. Kvenvolden, pers. comm.).

Using organic-carbon values as a guide, we exhaustively extracted either 100 or 150 grams (wet wt.) of sediment with acetone-methanol (9:1 by vol.), using a ball mill. Crude extracts were transferred to ethyl ether and washed with water to remove salts. Types and quantities of pigments were determined from the absorption spectra recorded in the 350 to $750 \mathrm{~nm}$ range, using a Perkin-Elmer 575 scanning spectrophotometer. Preliminary purification of pigments was accomplished by gelpermeation chromatography with Sephadex LH-20, using tetrahydrofuran as the mobile phase. Sephadex fractions, if they contained sufficient pigment, were treated with diazomethane to convert free acid substituents to methyl esters. Diazomethane was generated from $\mathrm{N}$-methyl- $\mathrm{N}^{\prime}$-nitro- $\mathrm{N}$-nitroso-guanadine in aqueous $\mathrm{KOH}(30 \%)$ overlayered by an ethereal solution of pigment. Chromatographic separation of diazomethanetreated isolates was performed on $1.5 \times 15 \mathrm{~cm}$ columns of commercial $4 \times$ powdered sugar developed with increasing percentages of acetone in petroleum ether $\left(30-60^{\circ} \mathrm{C}\right)$. The largest chlorin isolate from sugar chromatography of Section 434-1-3 extract was dissolved in ethyl ether and extracted with increasing percentages of aqueous $\mathrm{HCl}$ (up to $33 \%$ by wt.).

The ether layer from $\mathrm{HCl}$ extraction, containing carotenoid pigments, was saponified with $\mathrm{KOH}(15 \%)$ in $\mathrm{MeOH}(90 \%)$ for 8 hours under nitrogen in the dark at room temperature. Pigments were then chromatographed on activated neutral alumina with increasingly concentrated acetone in petroleum ether $\left(30-60^{\circ} \mathrm{C}\right)$. Carotenoids were dissolved in $n$-hexane, extracted into methanol $(45 \%)$, and re-chomatographed. Absorption spectra were recorded in $n$-hexane, and benzene to allow for known effects of solvents upon the absorption maxima of these polyene pigments.

All procedures were carried out in the dark or under dim yellow light. Pigment solutions were kept cold and under nitrogen whenever possible. Isolates were stored without solvent under nitrogen in a freezer. All solvents, except petroleum and ethyl ethers, were redistilled be- 
fore use. Ethyl ether and tetrahydrofuran were allowed to stand over activated basic alumina in order to remove peroxides.

\section{RESULTS}

Tetrapyrrole-pigment yields range from a barely detectable level of less than $0.002 \mu \mathrm{g} / \mathrm{g}$ in two middleMiocene samples to over $4 \mu \mathrm{g} / \mathrm{g}$ in a shallow Pleistocene sample. Table 1 is a compilation of the pigment data.

Yields of tetrapyrrole pigments decrease in relation to organic-carbon content with increasing depth of burial (Table 1). Figure 1 is a plot of the pigment-yield index (defined here as tetrapyrrole pigment in $\mu \mathrm{g} / \mathrm{g}$ sediment wet wt. divided by organic carbon in per cent dry weight) versus depth of burial. A rapid decrease in that portion of organic carbon represented as tetrapyrrole pigment occurs to a depth of burial of about 125 meters. Below 125 meters, this rate of decrease is much less. An inverse relationship between pigment yields and depth of sediment burial has been reported previously (Baker and Smith, 1973; Smith and Baker, 1974). Further, an effect of in situ sediment environment upon tetrapyrrole-pigment survival is seen by examination of Figure 1. Although the rate of pigment loss at Site 436 is similar to that at Sites 434 and $\mathbf{4 3 5}$, yields are markedly less at Site 436 for similar depths of burial. Since sediments at all three sites are hemipelagic, since organic-carbon values do not vary greatly with depth, and since similar influx of organic matter is assumed, the lower yield of tetrapyrrole pigments for Site 436 must be attributed to post-depositional reactions.

Based on chromatographic behavior, $\mathrm{HCl}$-partition data, and absorption spectra, there are at least eight, and possibly 10 , tetrapyrroles of the chlorin type in these Japan Trench sediments. Chlorins isolated from shallow sections (about 4-100 m) exhibit pheophorbide$a$-like absorption spectra. Figure 2 compares the absorption spectra for the major chlorin from Section 434-1-3 (Pleistocene) and for authentic pheophorbide- $a$ methyl ester. Chlorins isolated from deeper sediments $(100-420$ m) exhibit absorption spectra with maxima shifted toward the blue region. These shifts are indicative of chlorins which have undergone reduction of ring-conjugating groups (e.g., 2-vinyl, 9-keto) and perhaps alteration of the isocyclic ring. Chlorins from Section 434-1-3, at 4 meters sub-bottom, have red maxima at $670 \mathrm{~nm}$, whereas chlorins from Section 434B-15-1, at 420 meters sub-bottom, have red maxima at $660 \mathrm{~nm}$ (Table 1). This trend has been noted previously and may be indicative of reduction with increasing depth of burial.

Table 2 shows the percentage of chlorins yielding absorption spectra with red maxima less than $664 \mathrm{~nm}$ (i.e., defunctionalized) in relation to depth of burial for the west (Sites 434, 435) and east (Site 436) walls of the Japan Trench. The data for Site 436 are scarce because of poor yields from these sediments. However, in the uppermost 100 meters of Site 436 there is a noticeable retardation in the rate of reduction, below which the reduction of conjugating groups appears to be very rapid and complete. This, as well as the poor pigment yields, could reflect the very high alkalinity and lessened sulfate reduction found from about 35 to 80 meters at Site 436 (Langseth, Okada, et al., 1978). One exception to this reduction of chlorin conjugating groups with increase in depth of burial is seen in Table 2 for pigments from 133 meters sub-bottom at Site 434. It has been suggested that Section 434-15-3, which corresponds to this exception, is in a repeated sequence of Pliocene strata and was collected from a younger zone between two older zones (Langseth, Okada, et al., 1978). Therefore, this sample may not be representative of the degree of chlorin reduction expected for this depth of burial at these sites.

The chlorin red maximum $(\sim 655-670 \mathrm{~nm})$, rather than the Soret band $(\sim 395-420 \mathrm{~nm})$, was chosen as an indicator of the stage of reduction, because of a slight blue shift $(\sim 2-4 \mathrm{~nm})$ in the position of the Soret band following diazomethane treatment of some isolates. In the absorption spectra of those chlorins showing shifted Soret bands there was an enhancement of a shoulder at about 680 to $695 \mathrm{~nm}$. The absolute position of the red maxima for these isolates remained unchanged. Because we suspected artifact formation at this stage of chlorin isolation from Sections 434-1-3 and 434-23-2 (Table 1), we treated authentic pheophorbide- $a$ in like manner. Treatment with diazomethane, in the presence of base, caused formation of a marked shoulder at $690 \mathrm{~nm}$ and a shift in the Soret band from $408.5 \mathrm{~nm}$ to $404.5 \mathrm{~nm}$. Ideally, only the methyl ester of pheophorbide- $a$ should result from this treatment and exhibit a totally unaltered chromophore. Figure 3 is a comparison of the absorption spectra of pheophorbide- $a$, before and after diazomethane-base treatment, and similarly treated chlorin isolates from Sections 434-1-3 and 434-23-2. $\mathrm{HCl}$ extractions of the Section 434-1-3 isolate removed a chlorin mixture containing "altered chlorin" from ether with $\mathrm{HCl}(20 \%$ by wt.), whereas the major unaltered pigment was extracted from ether with $\mathrm{HCl}(30-33 \%)$. The "altered chlorin" displayed shifted Soret bands and represented about 10 per cent of the total isolate. Judging from absorption spectra, $\mathrm{HCl}$ partition, and known reactions of chlorins, we conclude that the "altered chlorin" is purpurin-18, or a very similar compound, generated from a pheophorbide.

Figure 4 shows proposed alterations of the isocyclic ring of a chlorin which would result in the behavior of the two aforementioned isolates. Apparently, the chlorin fraction before diazomethane treatment contained pheophytin, pheophorbide, and small amounts of this "altered chlorin." During esterification, in the presence of alkali (KOH), "unstable chlorin"' is likely to be formed from pheophorbide in the isolate or generated from pheophytin in vitro. "Unstable chlorin" in freeacid form converts to purpurin-18, while the ester form becomes purpurin-7 (Fischer and Stern, 1940). Purpurin-18 formation is favored by the continued presence of base (Seely, 1966). Methyl esters of pheophorbide- $a$ and purpurin- 18 have $\mathrm{HCl}$ numbers around 20 , whereas purpurin-7 has an $\mathrm{HCl}$ number of 11 . Pheophytin- $a$ requires about 30 per cent $\mathrm{HCl}$ for extraction from ether 
TABLE 1

Pigments Isolated from Samples of Sites 434, 435, and 436

\begin{tabular}{|c|c|c|c|c|c|c|c|c|c|c|c|c|c|c|c|c|}
\hline Section & $\mathrm{Age}^{\mathrm{a}}$ & Lithologic Descriptiona & $\begin{array}{l}\text { Sub-Bottom } \\
\text { Deptha } \\
\text { (m) }\end{array}$ & $\begin{array}{c}\text { Organic } \\
\text { Carbonb } \\
\text { (dry wt.\%) }\end{array}$ & $\begin{array}{c}\text { Total Tetrapyrrole } \\
\text { Pigmentc } \\
\text { ( } \mathrm{\mu g} / \mathrm{g} \text { sediment, wet wt.) }\end{array}$ & $\begin{array}{c}\text { Chromatographic } \\
\text { Behavior }^{d}\end{array}$ & & & & $\begin{array}{l}\text { ption } S p \\
\text { il ether st } \\
(\mathrm{nm})\end{array}$ & $\begin{array}{l}\text { sectrum } \\
\text { solvent) }\end{array}$ & & & & $\begin{array}{l}\text { Per Cent of } \\
\text { Total Pigment }\end{array}$ & Pigment Type \\
\hline $434-1-3$ & $\begin{array}{l}\text { Late } \\
\text { Pleistocene }\end{array}$ & $\begin{array}{l}\text { Dark-green } \\
\text { diatomaceous ooze }\end{array}$ & 4 & 0.8 & $\begin{array}{c}4.055 \text { plus } \\
0.288 \\
\text { (carotenoid) }\end{array}$ & $\begin{array}{l}\text { S } \\
\text { F, 5-25 } \\
\text { F, 5-25 } \\
\text { F, } 5-25 \\
\text { F, } 50 \\
\text { F, } 90\end{array}$ & $\begin{array}{l}\text { (395) } \\
\begin{array}{r}408 \\
409 \\
404 \\
403\end{array}\end{array}$ & 410 & 423 & $\begin{array}{l}(506) \\
444 \\
(506)\end{array}$ & $\begin{array}{r}542 \\
472 \\
536 \\
536 \\
536 \\
536\end{array}$ & $\begin{array}{l}611 \\
620 \\
610 \\
610 \\
610\end{array}$ & $\begin{array}{l}669.5 \\
670 \\
668 \\
669 \\
668\end{array}$ & (690) & $\begin{array}{r}1.2 \\
-4.8 \\
46.5 \\
43.5 \\
5.2\end{array}$ & $\begin{array}{l}\text { Chlorin } \\
\text { Carotenoid } \\
\text { Chlorin(s), } \mathrm{HCl}=20 \\
\text { Chlorin HCl } \mathrm{HC} \\
\text { Chlorin } \\
\text { Chlorin }\end{array}$ \\
\hline $434-15-3$ & $\begin{array}{l}\text { Early } \\
\text { Pliocene }\end{array}$ & $\begin{array}{l}\text { Dark-green } \\
\text { muddy diatomite }\end{array}$ & 133 & 0.5 & 0.370 & $\begin{array}{l}\text { F. } 5 \\
\text { F. } 25\end{array}$ & $\begin{array}{l}394 \\
399\end{array}$ & & & & $\begin{array}{l}(536) \\
(536)\end{array}$ & $\stackrel{615}{-}$ & $\begin{array}{l}668 \\
663\end{array}$ & & $\begin{array}{l}61.6 \\
38.4\end{array}$ & $\begin{array}{l}\text { Chlorin } \\
\text { Chlorin }\end{array}$ \\
\hline $434-23-2$ & Pliocene & $\begin{array}{l}\text { Dark-green } \\
\text { spicular } \\
\text { diatomaceous mudstone } \\
\text { \& carbonate pebbles }\end{array}$ & 208 & 0.7 & 0.548 & $\begin{array}{l}\text { F } \\
\text { S, } 5 \\
\text { S, 25 } \\
\text { S, } 50-75\end{array}$ & $\begin{array}{r}(398) \\
395 \\
398 \\
400\end{array}$ & 408 & & $\begin{array}{l}(505) \\
(500) \\
506\end{array}$ & $\begin{array}{l}(536) \\
(536) \\
536\end{array}$ & $\begin{array}{l}610 \\
610 \\
610 \\
-\end{array}$ & $\begin{array}{l}665 \\
664 \\
663 \\
663\end{array}$ & (690) & $\begin{array}{r}34.9 \\
24.4 \\
33.3 \\
7.4\end{array}$ & $\begin{array}{l}\text { Chlorin } \\
\text { Chlorin } \\
\text { Chlorin } \\
\text { Chlorin }\end{array}$ \\
\hline $434 \mathrm{~B}-15-1$ & Pliocene & $\begin{array}{l}\text { Dark-olive vitric } \\
\text { diatomaceous } \\
\text { mudstone }\end{array}$ & 420 & 0.6 & 0.532 & $\begin{array}{l}\text { S } \\
\text { F.5 } \\
\text { F, 25 } \\
\text { F, } 50-75\end{array}$ & $\begin{array}{c}396 \\
396 \\
(396)\end{array}$ & $\begin{array}{l}(408) \\
(405) \\
405 \\
402\end{array}$ & & (505) & $\begin{array}{l}(536) \\
(536) \\
(536)\end{array}$ & $\begin{array}{l}600 \\
610 \\
610\end{array}$ & $\begin{array}{l}665 \\
661 \\
660 \\
666\end{array}$ & & $\begin{array}{r}17.3 \\
27.6 \\
45.6 \\
9.5\end{array}$ & $\begin{array}{l}\text { Chlorin } \\
\text { Chlorin } \\
\text { Chlorin } \\
\text { Chlorin }\end{array}$ \\
\hline $435-5-4$ & $\begin{array}{l}\text { Early } \\
\text { Pleistocene }\end{array}$ & $\begin{array}{l}\text { Dark-olive muddy } \\
\text { diatomaceous ooze }\end{array}$ & 41 & 0.4 & 1.754 & $\begin{array}{l}\text { S } \\
\text { F, 5-10 } \\
\text { F, 15 } \\
\text { F, 25 } \\
\text { F, } 74,90\end{array}$ & $(398)^{396}$ & $\begin{array}{l}409 \\
411 \\
406 \\
404\end{array}$ & & $\begin{array}{l}(505) \\
(505)\end{array}$ & $\begin{array}{l}(536) \\
(536) \\
(536) \\
(536) \\
(536)\end{array}$ & $\begin{array}{l}- \\
610 \\
610 \\
610 \\
610\end{array}$ & $\begin{array}{l}667 \\
668 \\
667 \\
665 \\
663\end{array}$ & & $\begin{array}{l}23.8 \\
3.8 \\
12.5 \\
15.1 \\
12.8\end{array}$ & $\begin{array}{l}\text { Chlorin } \\
\text { Chlorin } \\
\text { Chlorin } \\
\text { Chlorin } \\
\text { Chlorin }\end{array}$ \\
\hline $435-13-2$ & $\begin{array}{l}\text { Early } \\
\text { Pliocene }\end{array}$ & $\begin{array}{l}\text { Olive diatomaceous } \\
\text { mud }\end{array}$ & 115 & 0.7 & 1.480 & $\begin{array}{l}\text { F, } 5 \\
\text { F, 25 } \\
\text { F, } 50-90\end{array}$ & $\begin{array}{l}\begin{array}{l}396 \\
(396) \\
398\end{array} \\
\end{array}$ & $\begin{array}{l}(406) \\
405\end{array}$ & & $\begin{array}{l}(505) \\
(505) \\
505\end{array}$ & $\begin{array}{l}536 \\
536 \\
536\end{array}$ & $\begin{array}{l}610 \\
610 \\
610\end{array}$ & $\begin{array}{l}666 \\
664 \\
663\end{array}$ & & $\begin{array}{l}35.8 \\
40.3 \\
23.9\end{array}$ & $\begin{array}{l}\text { Chlorin } \\
\text { Chlorin } \\
\text { Chlorin }\end{array}$ \\
\hline $436-7-4$ & Pleistocene & $\begin{array}{l}\text { Light-olive muddy } \\
\text { diatomaceous ooze }\end{array}$ & 61 & 0.6 & 0.293 & $\begin{array}{l}\text { S } \\
\text { F,5 } \\
\text { F, 2S } \\
\text { F, } 50\end{array}$ & $\begin{array}{l}398 \\
(396) \\
(398)\end{array}$ & $\begin{array}{l}(410) \\
409 \\
407 \\
404\end{array}$ & & $\begin{array}{l}506 \\
(505) \\
(505)\end{array}$ & $\begin{array}{c}536 \\
536 \\
(536)\end{array}$ & $\begin{array}{l}610 \\
610 \\
610 \\
610\end{array}$ & $\begin{array}{l}665 \\
668 \\
665 \\
663\end{array}$ & & $\begin{array}{r}23.3 \\
41.8 \\
30.5 \\
4.5\end{array}$ & $\begin{array}{l}\text { Chlorin } \\
\text { Chlorin } \\
\text { Chlorin } \\
\text { Chlorin }\end{array}$ \\
\hline $436-11-4$ & Late Pliocene & $\begin{array}{l}\text { Light-olive vitric } \\
\text { diatomaceous mud }\end{array}$ & 99 & 0.4 & 0.119 & $\begin{array}{l}\mathrm{S} \\
\mathrm{F}\end{array}$ & $\begin{array}{l}396 \\
396\end{array}$ & (409) & & (505) & $\begin{array}{l}536 \\
536\end{array}$ & $\begin{array}{l}610 \\
610\end{array}$ & $\begin{array}{l}666 \\
663\end{array}$ & & $\begin{array}{l}37 \\
63\end{array}$ & $\begin{array}{l}\text { Chlorin } \\
\text { Chlorin }\end{array}$ \\
\hline $436-19-2$ & $\begin{array}{l}\text { Early } \\
\text { Pliocene }\end{array}$ & $\begin{array}{l}\text { Light-olive vitric } \\
\text { diatomaceous mud }\end{array}$ & 172 & 0.2 & 0.121 & F & $(400)$ & 411 & & (505) & 536 & 610 & 661 & & - & Chlorin \\
\hline $436-24-1$ & $\begin{array}{l}\text { Early } \\
\text { Pliocene }\end{array}$ & $\begin{array}{l}\text { Olive vitric } \\
\text { diatomaceous mud }\end{array}$ & 218 & 0.2 & 0.051 & $\mathrm{~F}$ & (400) & 410 & & (505) & 536 & 610 & 663 & & - & Chlorin \\
\hline $436-31-1$ & Mid-Miocene & $\begin{array}{l}\text { Light-green vitric } \\
\text { diatomaceous } \\
\text { mudstone }\end{array}$ & 284 & 0.2 & 0.002 & - & & & & & & $\sim 660$ & & & - & Chlorin \\
\hline $436-36-3$ & Mid-Miocene & $\begin{array}{l}\text { Tan radiolarian } \\
\text { diatomaceous } \\
\text { mudstone }\end{array}$ & 335 & - & trace & - & & & & & & $\sim 660$ & & & - & Chlorin \\
\hline \multicolumn{17}{|c|}{$\begin{array}{l}\text { a } \\
\text { b Langseth, Okada, et al. (1978). } \\
\text { Cource: DSDP laboratory. } \\
\text { dS. F F refer to slow- or fast-moving fraction on Sephadex LH-20. Numbers refer to percentage of acetone in petroleum ether to elute pigment from powdered sugar. }\end{array}$} \\
\hline
\end{tabular}




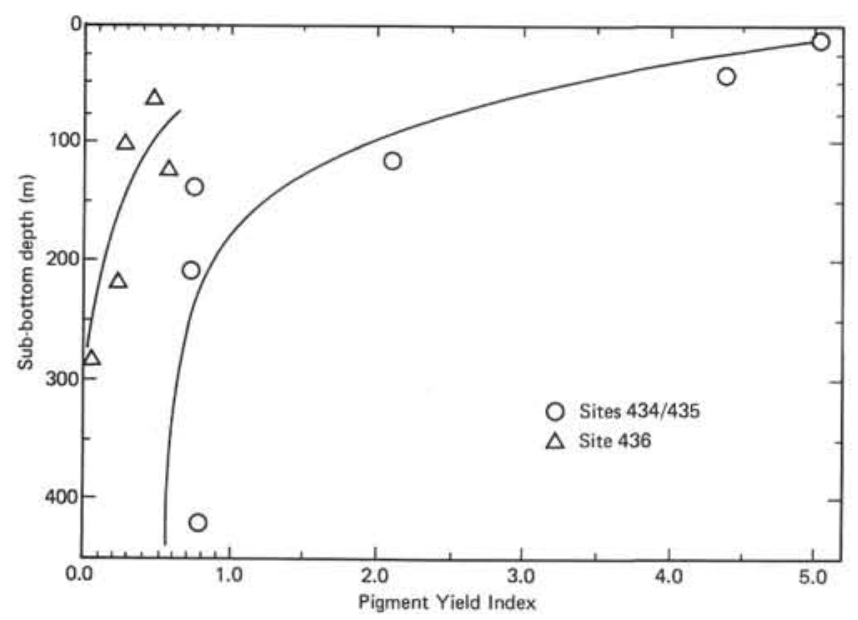

Figure 1. Tetrapyrrole pigment yield index versus sub-bottom depth. See text.

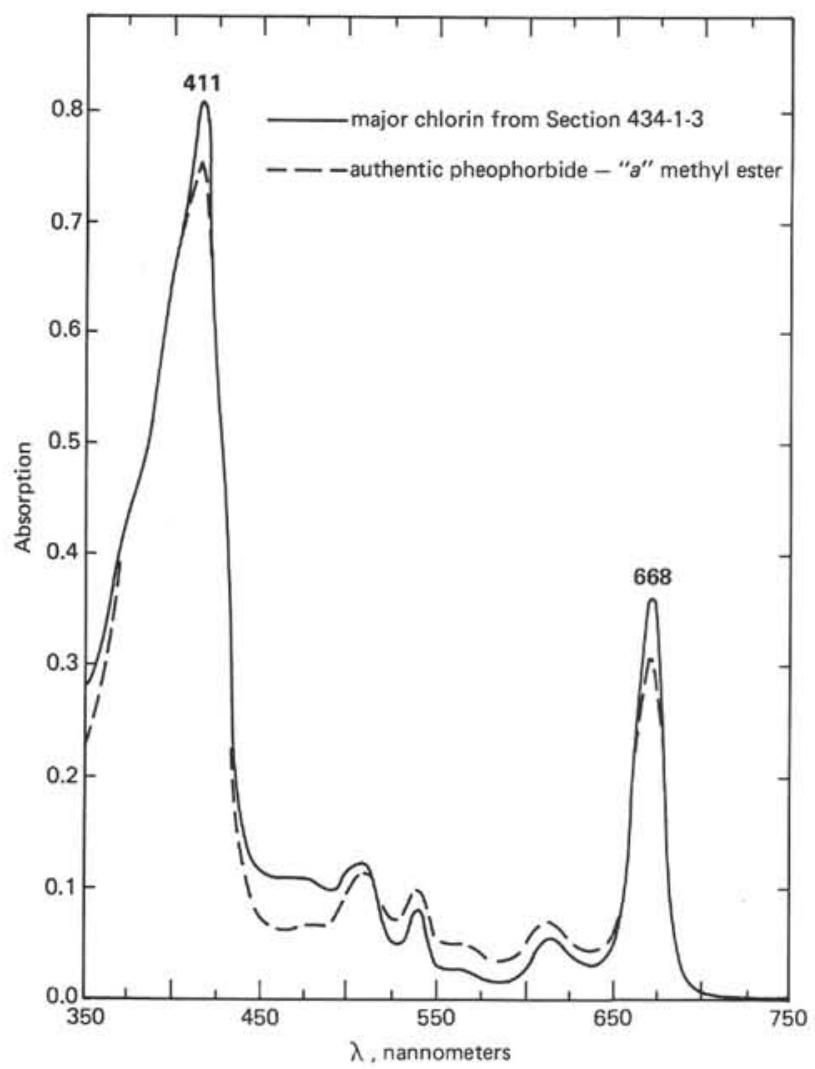

Figure 2. Absorption spectra of the major Pleistocene chlorin isolated from Section 434-1-3 and of authentic pheophorbide-a methyl ester. Solvent: tetrahydrofuran.

(Seely, 1966; Fischer and Stern, 1940). The main isolate from Section 434-1-3 was extractable from ether only with 30 to 33 per cent $\mathrm{HCl}$ and exhibited an unaltered spectrum (Fig. 1), whereas the "altered chlorins" ex-
TABLE 2

Percentage of Chlorins with Red Maxima below $664 \mathrm{~nm}$ in Relation to Sub-Bottom Depth

\begin{tabular}{clcc}
\hline $\begin{array}{c}\text { Sub-Bottom } \\
\text { Depth } \\
(\mathrm{m})\end{array}$ & \multicolumn{1}{c}{ Age } & $\begin{array}{c}\text { Sites 434, 435 } \\
\text { (west trench wall) }\end{array}$ & $\begin{array}{c}\text { Site 436 } \\
\text { (east trench wall) }\end{array}$ \\
\hline 4 & Late Pleistocene & $0 \%$ & - \\
41 & Early Pleistocene & $13 \%$ & - \\
61 & Pleistocene & - & $4 \%$ \\
99 & Late Pliocene & - & $63 \%$ \\
115 & Early Pliocene & $64 \%$ & - \\
133 & Early Pliocene & $38 \%$ & - \\
172 & Early Pliocene & - & $100 \%$ \\
208 & Pliocene & $65 \%$ & - \\
218 & Early Pliocene & - & $100 \%$ \\
284 & Mid-Miocene & - & $100 \% \mathrm{a}$ \\
335 & Mid-Miocene & - & - \\
420 & Pliocene & $91 \%$ & $\mathrm{a}$ \\
\hline
\end{tabular}

${ }^{\mathrm{a}}$ Based solely on examination of absorption spectra of crude extracts.

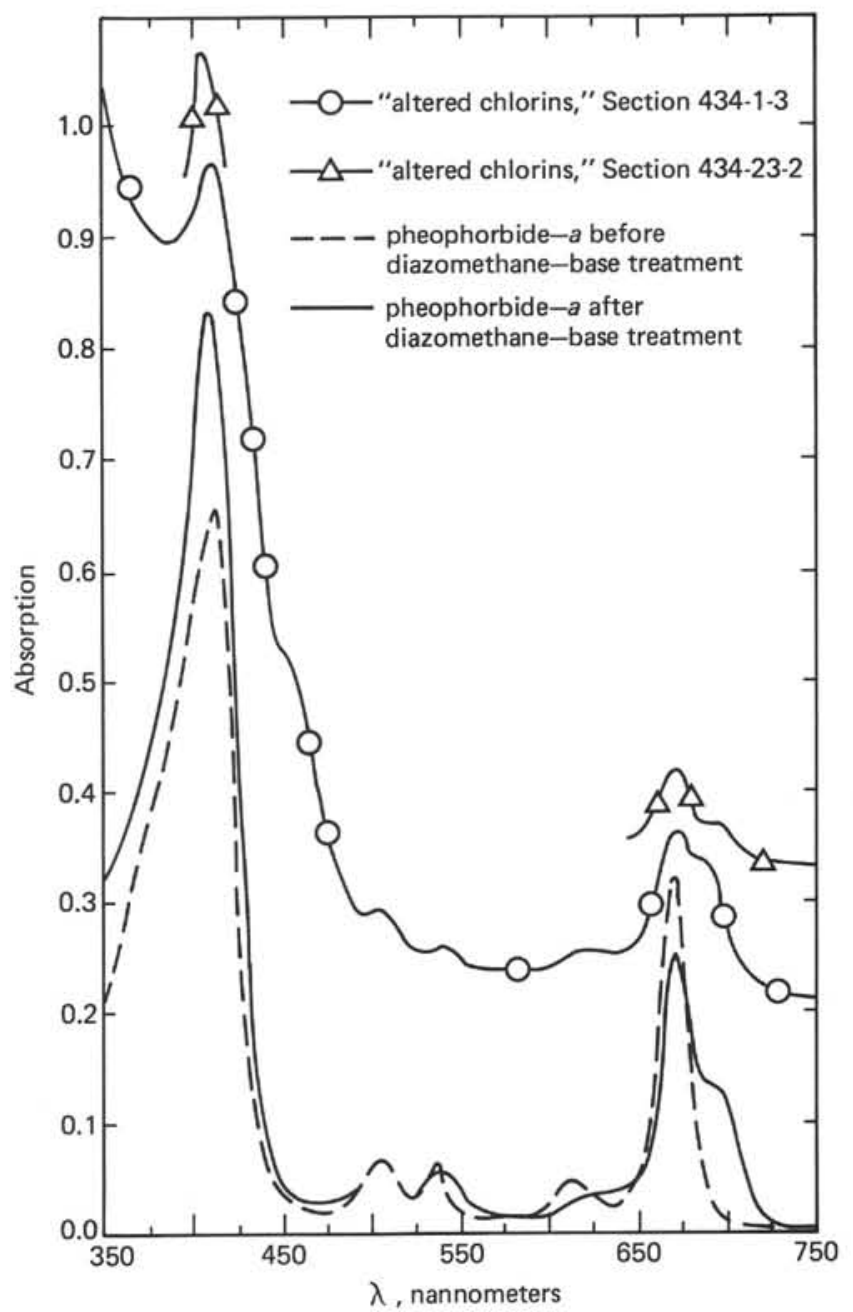

Figure 3. Absorption spectra of pheophorbide-a before and after treatment with diazomethanebase, and of "altered chlorins" isolated from Sections 434-1-3 and 434-23-2. Partial spectrum. Solvent: ethyl ether. Base lines shifted vertically. 


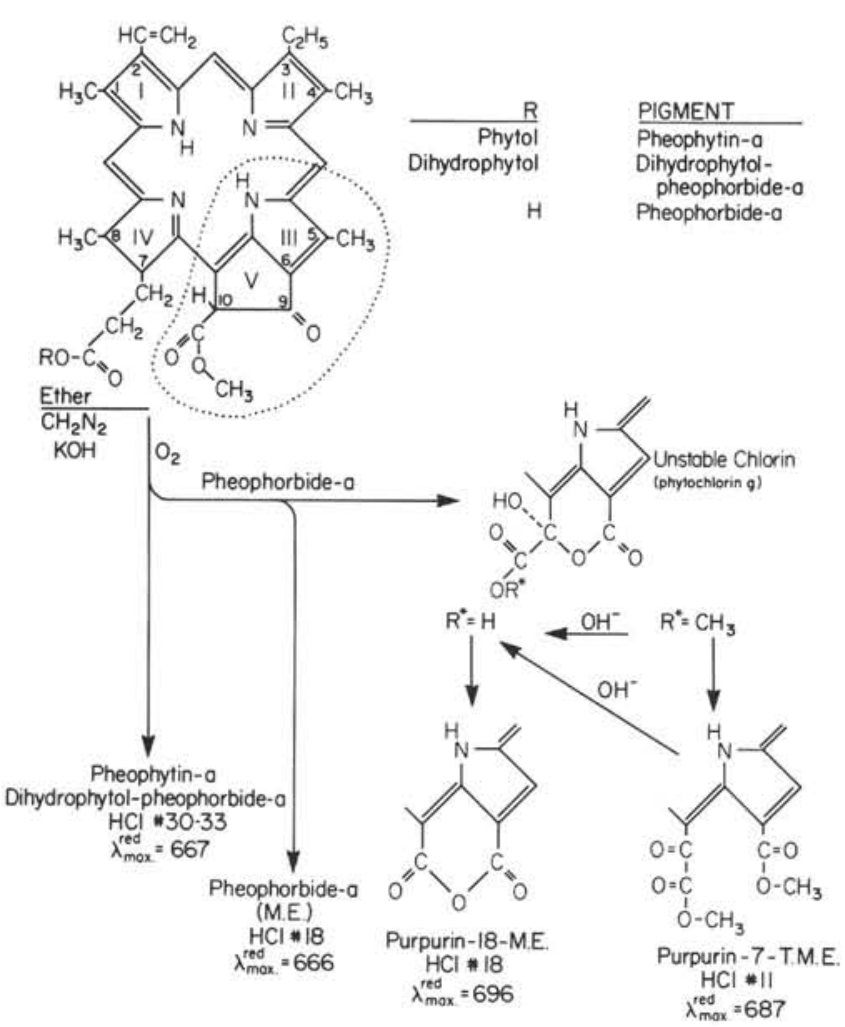

Figure 4. Proposed alkali-catalyzed oxidative alterations of Site 434 chlorins.

tracted with 20 per cent $\mathrm{HCl}$. Lower percentages $(3,5$, 10 , and $15 \%$ ) failed to extract pigment from the ethereal solution. Not all absorption in the 680 to $690 \mathrm{~nm}$ region is due to artifact formation, because spectra recorded prior to diazomethane-base treatment possess this band. Apparently the standard workup employed herein enhanced this absorption band. A modified procedure, in which the diazomethane is trapped in ether, the $\mathrm{KOH}$ is removed by water wash, and chlorin isolates are reacted in the absence of base, is being adopted (cf. Fuhrhop and Smith, 1975). We do not know to what extent the $690-\mathrm{nm}$ peak in chlorin spectra previously reported (Smith and Baker, 1974; Peake et al., 1974; Baker et al., in press) is indicative of geologic pigment or laboratory artifact. However, the presence of these "altered chlorins" only in Site 434 samples appears to preclude alteration due to thawing of the Leg 56 sample suite.

Chromatography on alumina of the carotenoid isolate yielded two fractions. Fraction 1, eluted with 5 per cent acetone in petroleum ether, had an indication of carotenoid-like absorption absorption in the region 430 to $450 \mathrm{~nm}$, but was severely obscured by other, less specifically absorbing species. Fraction 2, eluted with 65 per cent acetone in petroleum ether, exhibited definite carotenoid absorption spectra. Fraction 2 absorption maxima are 419,443 , and $470 \mathrm{~nm}$ in $n$-hexane; 420,444 , and $471 \mathrm{~nm}$ in methanol; and 430,455 , and $480 \mathrm{~nm}$ in benzene. The carotenoid is highly hypophasic to partition by $n$-hexane and 95 per cent methanol. Absorption spectra resemble closely the spectral characteristics of carotenoid isolates reported from Santa Barbara Basin and Mississippi Sound sediments (Schwendinger, 1969). Alterations of the carotenoid may have occurred prior to its recognition in the extracts of Section 434-1-3. Specifically, diazomethane treatment, $\mathrm{HCl}$ partition, alkali saponification, and exposure to activated alumina could produce artifacts. However, a very polar carotenoid was isolated, as determined from chromatographic and hexane-methanol partition trials. Considering that diatoms were the major source of organic carbon in Leg 56 sediments, it seems most likely that the original carotenoid would have been fucoxanthin, or one of the fucoxanthin series. Carotenoids previously have been isolated from Cariaco Trench sediments (Watts et al., 1975; Watts and Maxwell, 1977). Carotenoid analyses of Black Sea shallow sediment samples showed a 40-to-1 decrease in abundance from the surface to about 3 meters sub-bottom (Peake et al., 1974), which indicates a rapid demise of the carotenoid chromophore. The C-40 tetraterpene skeleton is more likely to survive, because perhydro- $\beta$-carotenes (i.e., carotanes) have been isolated from the Green River shales (Murphy et al., 1967).

\section{SUMMARY AND CONCLUSIONS}

DSDP Leg 56 provided core samples from the west (Sites 434, 435) and east (Site 436) slopes of the Japan Trench. Sample depth ranged from 4 to 420 meters subbottom, and sample age from Pleistocene to middle Miocene.

Tetrapyrrole-pigment yields ranged from $4 \mu \mathrm{g} / \mathrm{g}$ in shallow Pleistocene sediments to a barely detectable level of less than $0.002 \mu \mathrm{g} / \mathrm{g}$ in the deeper middleMiocene sediments. All tetrapyrrole pigments were of the chlorin type, free-base and metalloporphyrins being absent.

Chlorin isolates from Japan Trench sediments showed the following characteristics: (1) Chlorins from shallow sediments exhibited pheophorbide-like absorption spectra and were early running during LH-20 separations, whereas chlorins from more deeply buried sediments exhibited reduced chromophores and were late running during chromatographic procedures. (2) "Altered chlorins" exhibiting red absorption as a shoulder in the 680 to $690 \mathrm{~nm}$ region were present, thus indicating the introduction of additional ring-conjugating groups.

Several trends in early chlorophyll diagenesis were observed: (1) Increased reduction of ring-conjugating groups of chlorins with depth, except in Section 43415-3; this exception may be explained by repetition of Pliocene strata. (2) Decreased yields of intact tetrapyrrole pigment as a component of the organic carbon with increase in depth of burial was observed. (3) The pigment yield per organic carbon is less for comparable depths of burial at Site 436 than at Sites 434 and 435 .

Carotenoid-like absorption was significant only in Section 434-1-3, a very shallow Pleistocene sample. A highly polar carotenoid isolate from this sample amounted to $0.288 \mu \mathrm{g} / \mathrm{g}$ sediment and is most likely an altered product of fucoxanthin, a pigment very abundant in diatoms. 
"Altered chlorin"' isolated from Leg 56 sediment samples exhibits absorption at $680-690 \mathrm{~nm}$ and is possibly purpurin-18. In vitro treatment of chlorins with alkali increases the concentration of this "altered chlorin." If purpurin-18, or other "chlorins" with cleaved isocyclic rings, unequivocally can be shown to be natural geopigments, several interesting questions would arise: To what extent does isocyclic-ring cleavage via purpurin formation contribute to rhodo- and etioseries generation? Does cleavage of the isocyclic ring at the chlorin stage in chlorophyll diagenesis aid in the removal of tetrapyrrole pigments from sediments by "activating" the macrocycle to subsequent oxidative cleavage? Can the occurrence of purpurins be used as an indicator of oxidizing conditions during deposition? Answers to these queries will be sought as chlorin-rich sediments from other areas are examined.

\section{ACKNOWLEDGMENTS}

This research was supported by the Oceanography Section of the National Science Foundation, Grants OCE 74-12438 A02 and OCE 77-07273. The authors thank Drs. Kenneth Winters of The University of Texas, Port Aransas, Texas, and Karl Schorno of Phillips Petroleum Company, Bartlesville, Oklahoma, for their reviews of this manuscript. The authors also thank Ms. Debra Murphy for invaluable laboratory assistance.

\section{REFERENCES}

Baker, E. W., 1969. Porphyrins. In Eglinton, G., and Murphy, M. T. J. (Eds.), Organic Geochemistry: New York-Heidelberg-Berlin (Springer-Verlag), pp. 464-497.

Baker, E. W., Palmer, S. E., and Huang, W. Y., 1977. Intermediate and late diagenetic tetrapyrrole pigments, Leg 41: Cape Verde Rise and Basin. In Lancelot, Y., Seibold, E., et al., Init. Repts. DSDP, 41: Washington (U.S. Govt. Printing Office), 825-837.

1978. Chlorin and porphyrin geochemistry of DSDP Leg 40 sediments. In Bolli, H. M., Ryan, W. B. F., et al., Init. Repts. DSDP, Supplement to Volumes $38,39,40$, and 41: Washington (U.S. Govt. Printing Office), 639-648

Baker, E. W., and Smith, G. D., 1973. Chlorophyll derivatives in sediments, Site 147. In Heezen, B. C., MacGregor, I. D., et al., Init. Repts. DSDP, 20: Washington (U.S. Govt. Printing Office), 943-947. 1975. Chlorophyll derivatives in DSDP Leg 14, 20, 26, 27, and 29 sediments. In Karig, D. E., Ingle, J. C., Jr., et al., Init. Repts. DSDP, 31: Washington (U.S. Govt. Printing Office, pp. 905-909.

Fischer, H., and Stern, A., 1940. Die Chemie des Pyrrols II. Band. Pyrrol-Farbstoffe S. Halfte: Leipzig (Akademische Verlagsgesellschaft), 84-120.

Fuhrhop, J. H., and Smith, K. M., 1975. Laboratory methods. In Smith, K. M. (Ed.), Porphyrins and Metalloporphyrins: Amsterdam (Elsevier), pp. 834-835.

Langseth, M., Okada, H., et al., 1978. Leg 56. Init. Core Descriptions DSDP.

Murphy, M. T. J., McCormick, A., and Eglinton, G., 1967. Perhydro- $\beta$-carotene in the Green River Shale. Science, 157, 1040-1042.

Palmer, S. E., and Baker, E. W., 1979. Tetrapyrrole pigments from IPOD Leg 47B, Hole 398D. In Ryan, W. B. F., Sibuet, J.-C., et al., Init. Repts. DSDP, 47B: Washington (U.S. Govt. Printing Office), 571-576.

Peake, E., Casagrande, D. J., and Hodgson, G. W., 1974. Fatty acids, chlorins, hydrocarbons, sterols, and carotenoids from a Black Sea core. In Degens, E. T., and Ross, D. A. (Eds.), The Black Sea: Geology, Chemistry, and Biology: Tulsa (Am. Assoc. of Petrol. Geol.).

Schwendinger, R. B., 1969. Carotenoids. In Eglinton, G., and Murphy, M. T. J. (Eds.), Organic Geochemistry: New York (Springer-Verlag).

Seely, G. R., 1966. The structure and chemistry of functional groups. In Vernon, L. P., and Seely, G. R. (Eds.), The Chlorophylls: New York (Academic Press), pp. 86-97.

Smith, G. D., and Baker, E. W., 1974. Chlorophyll derivatives in DSDP Leg 22 sediments. In von der Borch, C. C., Sclater, J. G., et al., Init. Repts. DSDP, 22: Washington (U.S. Govt. Printing Office), 677-679.

Watts, C. D., and Maxwell, J. R., 1977. Carotenoid diagenesis in a marine sediment. Geochim. Cosmochim. Acta, 41, 493-497.

Watts, C. D., Maxwell, J. R., and Kjøsen, H., 1975. The potential of carotenoids as environmental indicators. In Campos, R., and Goni, J. (Eds.), Advances in Organic Geochemistry 1975: Madrid (Enadimsa), pp. 391-413. 